by passing a spark between two points attached to the breeching. I believe this would be really practicable and useful. August 9

J. F. TenNant

\section{MAGNETICAL AND METEOROLOGICAL WORK AT BOMBAY}

$W^{E}$ have received from Mr. C. Chambers, F.R.S., the Director of the Colaba Observatory, Bombay, three memoirs, to appear eventually as appendices to the volume; observations dealing with (I) the Absolute Direction and Intensity of the Earth's Magnetic Force at Bombay, and its Secular and Annual Variation, (2) on the Lunar Variations of Magnetic Declination at Bombay, and (3) a description of a new Self-Registering Rain Gauge. In the first memoir Mr. Chambers refers to the diminution of terrestrial magnetic action with increase of height above the ground. He states, "I am aware that experiments have at times been made to determine the effect upon the terrestrial magnetic force, of change of elevation or depression, both upon mountains and in mines; and it may be that such have been made also upon high buildings; but excepting the observations made in the vaults of the Paris Observatory, which I have not seen any discussion of with reference to this point, I believe that no long series of observations-capable of detecting small differences of the kind now pointed outhave been made elsewhere than at Bombay; and that the facts so strongly brought to light by the Bombay observations have not previously been forcibly commented on. It has now been shown-by the discussion of independent observations in each case-that diminution of effect with increase of height extends to- $(I)$ the Secular Variation of Declination, (2) the Secular Variation of Horizontal Force, and (3) the Diurnal Inequality of Horizontal Force. Consistent testimony of this kindeven allowing for the possibility of explaining the first case on a different hypothesis-gives probability to the supposition that the phenomenon of sensible diminution of terrestrial magnetic action with moderate and practically attainable elevations above the earth's surface is general."

The object of the new rain gauge is to produce a complete record of rain-fall by means of photography, with this additional advantage, that whenever a barometer is kept in continuous operation there need be no additional expense in working the rain gauge.

\section{SCIENCE IN $7 A P A N$ *}

PROF. W. E. GRIFFIS writes us a very encouraging letter from Fukuwi, Japan, where he is giving practical instruction in a chemical laboratory established a year ago. Sixty students attend his daily lectures on chemistry and physics, properly illustrated by experiments, and twelve students do actually practise in the chemical laboratory. What he says of Japan is equally true here in the United States, only that the rubbish of astrology and Chinese philosophy, which prevent rapid progress there, are here represented by notions not less common nor less obstinate. He says:- "In teaching physical science in Japan, one has need to begin at the lowest foundation, to demonstrate everything, and to clear away much rubbish of astrology, Chinese notions of philosophy, falsely so called, \&c.; ; yet the students are fairly intelligent, and promise hopefully to fill, in some measure, the greatest educational need of the country-good teachers."

The following will also merit attention :- "It may please you to know that Japan, just entering upon her course of modern civilisation, has begun by not only assigning a

* From the Iowa "School Laboratory of Physical Science." foremost place to physical science in her schools, but has already established several laboratories, in which students receive practical instruction from German and American professors. The chief laboratory in Osaka is presided over by a German professor, having nearly one hundred students. Another laboratory, it is expected, will be established in Yeddo. There is one in the province of Kaga, in charge of a German professor; another, also under a German, is at Shidzoka, in the province of Suruga. The laboratory in Fukuwi, province of Echeyen, has been established nearly a year." This is the laboratory of Prof. Griffis, above spoken of.

It gives us, indeed, great pleasure to record these significant evidences of progress in the far-off Japan. These facts, as well as many others, show that at length commerce, the arts, and physical science, have commenced their missionary career in Japan, and will soon introduce the blessings of civilisation in that great country leaving the Japanese and Chinese gods to take care of themselves, if they can.

\section{THE "HASSLER" EXPEDITION}

THE GALAPAGOS ISLANDS

THE numbers of NATURE for July it and I 8 contain reports from Prof. Agassiz himself of his Hassler Expedition; we are glad to be able to furnish the following continuation of these reports from a writer in the Nere York Tribune who accompanies the Expedition:-

"About sundown on Thursday June 6 we bade good-bye to the Ossipee and to Payta, and, with a fair wind and smooth sea, started for the Galapagos. Darwin's account of this archipelago had excited our curiosity and interest to the highest degree. Of course our visit was all too short to settle the many interesting questions which his narrative suggests. We landed on Charles early Monday afternoon, June Io, and left early Wednesday morning. We landed at Tagus Cove, on Albemarle, Thursday morning, and remained until Friday afternoon. On Saturday at noon we anchored off James Island, and remained until Sunday at ro o'clock, when we visited Jervis Island, and remained until sunrise on Monday. We anchored at Indefatigable Island on Monday by 9 o'clock A.M., and were detained repairing our engine until Wednesday afternoon, June 19, when we started for Panama. In so brief a visit to so remarkable an archipelago, no conclusions can pro. perly be drawn from what we did not see, and yet one of the most interesting points of inquiry was precisely one that can be definitely settled by negative testimony onlythe inquiry whether plants and animals found on one island are wanting on the other islands in the group. That this should be the case is not incredible; even on the continent we sometimes find plants and animals confined to very narrow localities. And although we had a very limited opportunity to examine the five islands on which we landed, our observations, as far as they go, tend to confirm the statements heretofore made that the Galapagos have a fauna and a flora decidedly of an American type, yet decidedly peculiar to themselves, and that even each island differs from the other islands; nay, that this difference extends, in some degree, to the fishes in the bays around their shores.

"The islands are to my eye much more recent in their formation than Juan Fernandez. Indeed, Narborough and Albemarle have so fresh a look that you could easily believe that there had been extensive eruptions there within the present century. Immense domes, 4,000 to 5,000 feet high, stand upon very flat truncated cones, twelve or fifteen miles in diameter. Over the whole surface of such mountains are scattered craters, chimneys, and small truncated cones. From many of these craters streams of lava have flowed toward the sea, some of them 